EUROPEAN CENTRAL BANK

WORKING PAPER SERIES

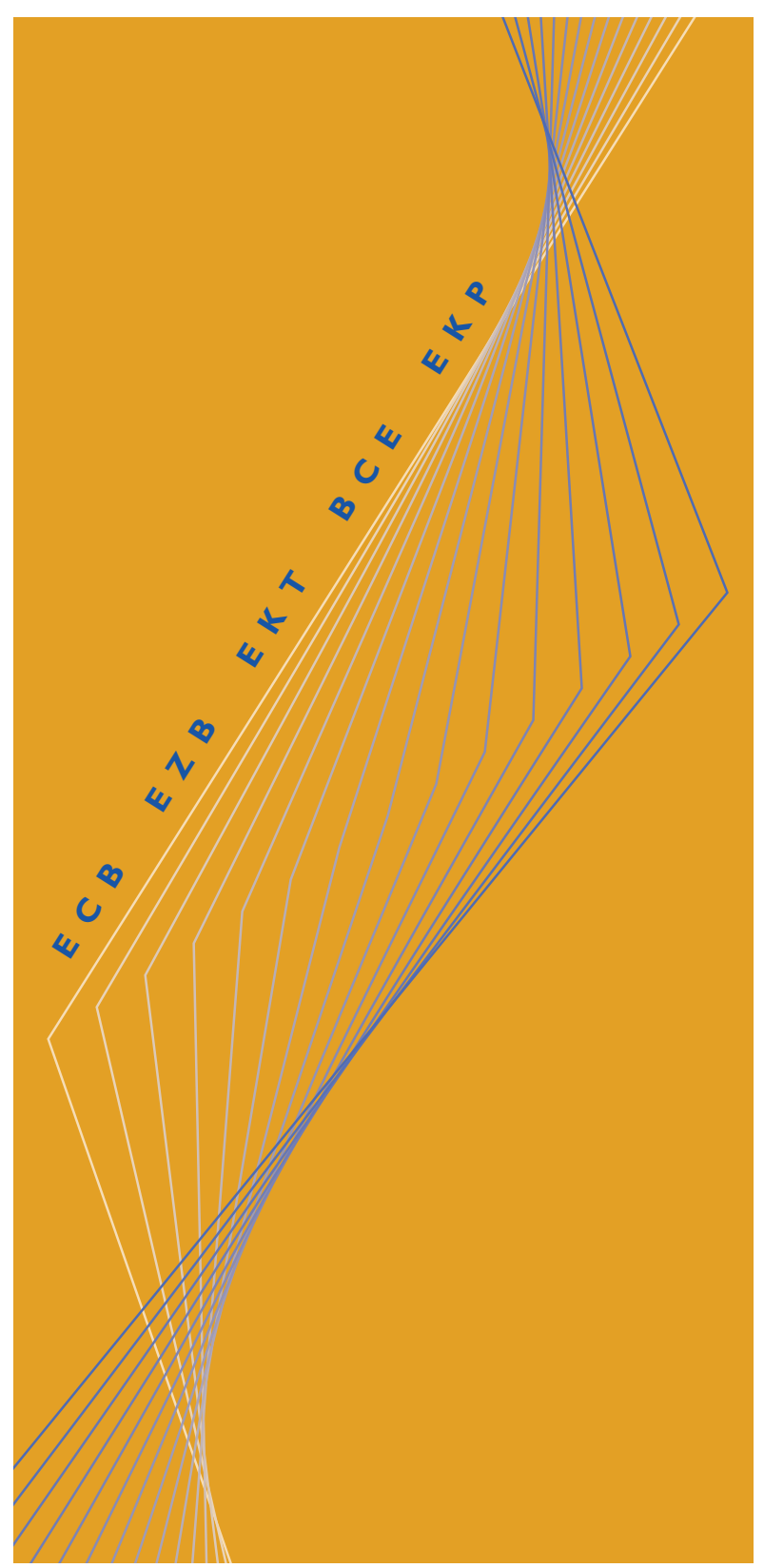

WORKING PAPER NO. I I

IS THE YIELD CURVE A

USEFUL INFORMATION

VARIABLE FOR THE

EUROSYSTEM?

JAN MARC BERK

AND PETER VAN BERGEIJK

FEBRUARY 2000 


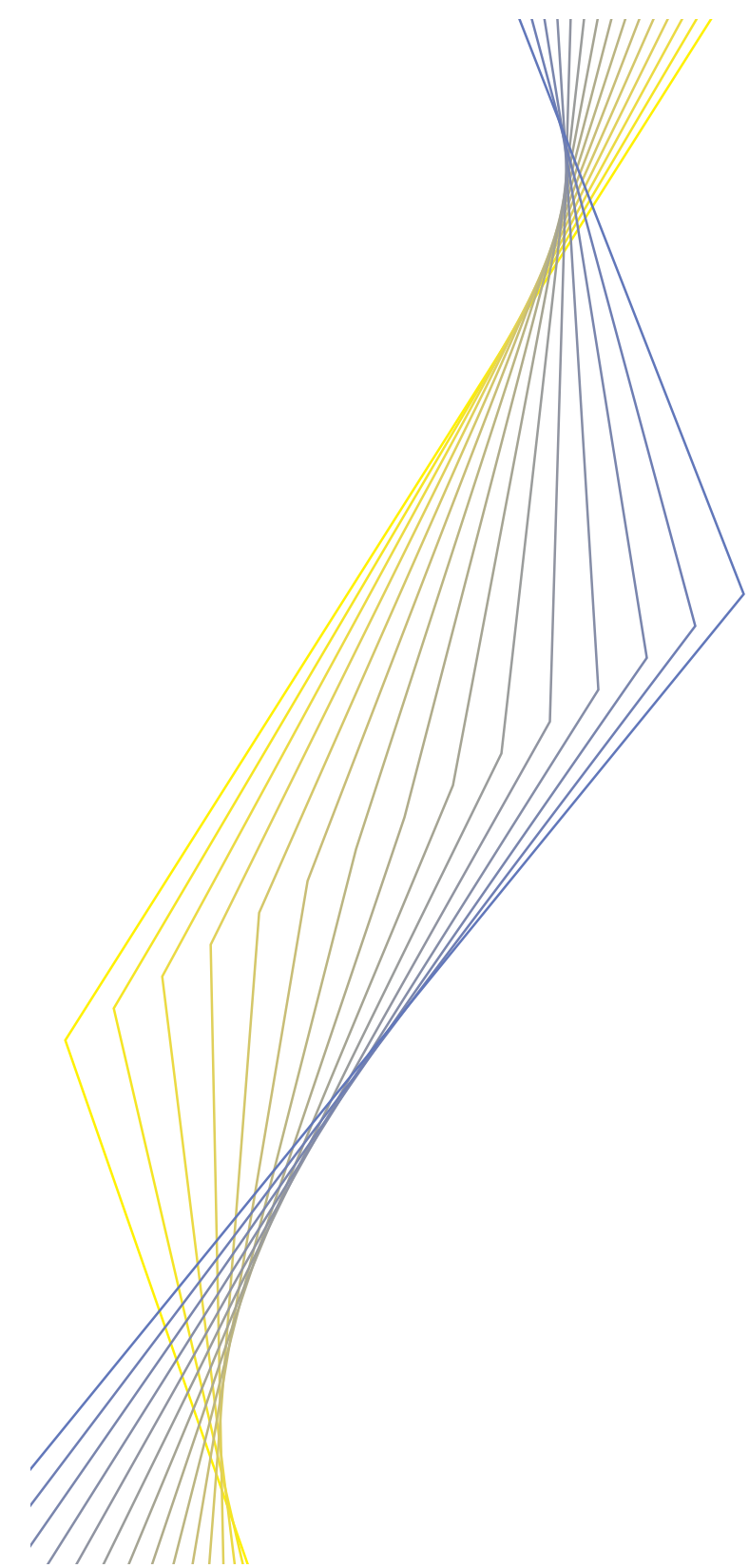

WORKING PAPER NO. I I

\title{
IS THE YIELD CURVE A USEFUL INFORMATION VARIABLE FOR THE EUROSYSTEM?
}

\author{
JAN MARC BERK* \\ AND \\ PETER VAN BERGEIJK**
}

FEBRUARY 2000

* Corresponding author. Monetary and Economic Policy Department, De Nederlandsche Bank, PO Box 98 I000 AB Amsterdam,The Netherlands. Email:j.m.berk@dnb.nl. **Group Economic Research, UBS, Switzerland. Work on this paper was conducted when the second author was at De Nederlandsche Bank. Views expressed are those of the authors and do not necessarily 
(C) European Central Bank, 2000

$\begin{array}{ll}\text { Address } & \text { Kaiserstrasse } 29 \\ & \text { D-60311 Frankfurt am Main } \\ & \text { GERMANY } \\ \text { Postal address } & \text { Postfach } 160319 \\ & \text { D-60066 Frankfurt am Main } \\ & \text { Germany } \\ \text { Telephone } & +496913440 \\ \text { Internet } & \text { http://www.ecb.int } \\ \text { Fax } & +496913446000 \\ \text { Telex } & 411144 \text { ecb d }\end{array}$

All rights reserved.

Reproduction for educational and non-commercial purposes is permitted provided that the source is acknowledged.

The views expressed in this paper are those of the author and do not necessarily reflect those of the European Central Bank.

ISSN 1561-0810 


\begin{abstract}
The focus of this paper is on the use of the yield curve in monetary policy making. Theoretical arguments and a multi-country empirical analysis with an explicit focus on the euro area suggest the need for caution in case the Eurosystem uses the yield curve as an information variable for monetary policy, because multiple theoretical explanations exist for an observed movement in the yield curve, suggesting that policy reactions cannot be prescribed unambiguously. In addition, the empirical analysis shows that, in contrast with earlier findings of, for example, Hardouvelis (1994) and Bernard and Gerlach (1996), the information content of the yield curve is fairly limited. For the individual European countries participating in the Eurosystem as well as for the euro area as a whole, the yield spread possesses only very limited information relating to future movements in the inflation rate and output growth, over-and-above the information contained in the history of the latter variables.
\end{abstract}




\section{Introduction}

The monetary policy strategy of the Eurosystem ${ }^{1}$ consists of three key elements. First, the Eurosystem's primary policy objective, price stability, has been quantitatively defined. Second, the strategy assigns a prominent role to money, as indicated by the announcement of a quantitative reference value for the growth rate of a monetary aggregate. And, third, the information provided to the policy maker by the development of (the components of) the money stock is supplemented by a broadly based assessment of the outlook for price developments and risks to price stability in the euro area as a whole. ${ }^{2}$ This assessment will be based on a wide range of economic indicators, and acknowledges that, although the monetary data contain information vital to informed policy making, in isolation they do not provide sufficient information about the economy in order to gear monetary policy at the maintenance of price stability.

Central to the third element of this strategy are information variables. An important question in this respect pertains to the necessary conditions for a particular variable to be used as an information variable for monetary policy purposes. Following Shigehara (1996) and Berk (1998), we define an information variable in terms of stability and predictability with respect to non-financial activity. That is, the relationship between the information variable and non-financial activity needs to be predictable. In addition, the information variable should possess leading indicator properties with respect to non-financial activity. We furthermore define non-financial activity to include inflation (logically linked to the ultimate objective of monetary policy, price stability) and real economic activity. The latter is also of interest for a central bank, since monetary actions undertaken to safeguard the objective of price stability in the face of disturbances can elicit real economic effects in the short run, especially when the degree of credibility of monetary policy is insufficient (Fuhrer, 1997). In this paper we concentrate on one possible information variable, the term structure of interest rates. We define the term structure as the relation between the yields to maturity for different terms to maturity. ${ }^{3}$

The objective of this paper is to review the information content of the term structure of interest rates with respect to future movements in inflation and real output, and to investigate whether this yield curve is useful to the Eurosystem for monetary policy purposes. In the

\footnotetext{
1 The Eurosystem comprises the ECB and the national central banks of the member states which have adopted the euro in stage three of EMU.

See Berk, Houben and Kakes (forthcoming) for a discussion of the monetary policy strategy of the Eurosystem.

In this paper we use the terms 'term structure' and 'yield curve' in an interchangeable fashion, which is, strictly speaking, not correct: the term structure is a particular yield curve (i.e. for zero-coupon bonds). See Shiller (1990), Svensson (1994) and Haubrich and Dombrosky (1996) for a discussion, and Deacon and Derry (1994) for details concerning the construction and estimation of various yield curves.
} 
past two decades, a good deal of empirical and theoretical work has been done regarding the information contained in the term structure (see Berk, 1998, for a recent review of the literature). Although the empirical research has been mainly directed at G-7 countries (see Jondeau and Ricart, 1999, for a recent example), work by, inter alia, Koedijk and Kool (1995), Bernard and Gerlach (1996) and Gerlach and Smets (1997) presents evidence for other (European) countries as well. Whereas these studies primarily focus on extracting information from the yield curve, Angeloni and Rovelli (1999) more explictly address the issue of the usefulness of the term structure for monetary policy purposes. Like the papers presented in the latter volume, the approach in this paper is largely empirical. Using data on a large number of countries and for the euro area as a whole, we try to assess whether the yield spread contributes significantly to the predictability of both inflation and output, overand-above simple autoregressive representations of the latter variables. We concur with Mishkin (1990a, 1990b) that this interpretation of information content is rather narrow, since no use is made of additional economic variables in combination with the slope of the yield curve. This criticism notwithstanding, we follow existing practice by using this interpretation. More specifically, the contribution of the paper is twofold. First, we combine results on the relationship between the term structure and, respectively, the future inflation rate and real economic activity. This is convenient, as both lines of inquiry have been discussed seperately in the literature. Second, and more important from a European monetary policy perspective, we conduct an empirical analysis on euro area-wide variables.

The paper is organised as follows. We first present theoretical arguments explaining why the yield curve should, in general, convey information regarding future price and output developments. The third section tries to ascertain empirically whether the yield curve contains information on future movements in the inflation rate and in output growth in the euro area and participating countries. Section IV concludes.

\section{A general discussion on the usefulness of the yield curve for monetary policy}

The theoretical basis for the information content as defined above consists of the combination of the Fisher equation and the expectations theory of the yield curve (Modigliani and Sutch, 1966). The (one-period) Fisher equation decomposes the one-period nominal interest rate roughly into a one-period ex ante real interest rate and the inflation 
expected one period ahead. ${ }^{4}$ The expectations theory of the yield curve is the most prevalent explanation of the term structure, and is based on the arbitrage condition that, after adjusting for risk, the expected return from holding for one period a bond that has $n$ periods to maturity is the same as the certain return from a one-period bond. Combining these theories gives us the following expression (for a formal derivation, see Tzavalis and Wickens, 1996):

$$
R(n, t)=E_{t} r(n, t)+E_{t} \pi(n, t)+\phi(n)
$$

where $R(n, t)$ denotes the yield to maturity at $t$ of a bond with $n$-periods to maturity. $E$ is the expectations operator, and the subscript pertains to the period in which the expectation is formed,

using information up to and including $t . r(n, t)$ is the average real interest rate over the current and next $n-1$ periods, $\pi(n, t)$ is the average inflation rate over the next $n$ periods and $\phi(n)$ is the average risk premium on an $n$-period bond until it matures. This risk premium is ex hypothesi constant under the expectations theory of the term structure. All rates are expressed in natural logarithms, save for the inflation rate, which is defined as the first difference of two logarithms.

Equation (1) can be interpreted as an $n$-period Fisher equation. Subtracting from (1) the (similar) $m$-period Fisher equation gives the slope of the yield curve between segments $n$ and $m$. For $m=1$ (the spot rate), the following equation emerges:

$$
R(n, t)-R(1, t)=E_{t}[r(n, t)-r(1, t)]+E_{t}[\pi(n, t)-\pi(1, t)]
$$

It follows from equation (2) that the slope of the yield curve (left hand side) provides information on the expected real interest rate spread, and on the market's expected inflation path (i.e. the change in the future $n$-period inflation rate from the 1-period inflation rate). Hence a potential identification problem exists: if these variables are not all perfectly correlated, the yield spread is a noisy forecast of any of them.

Two extreme cases can be identified. Mishkin (1990b, pp. 79-80) states that the slope of

\footnotetext{
4 In a more general form, the Fisher equation also incorporates an inflation risk premium and the conditional variance of inflation. These factors - which are quantitatively unimportant (Tzavalis and Wickens, 1996, p.105) are omitted here for expositional ease.
} 
the yield curve will provide an exact measure of the market's expected inflation path if and only if all the following restrictive assumptions are satisfied: (i) the expected real interest rate is constant over time (horizontal real term structure), (ii) expectations are formed rationally and (iii) risk premia are constant over time. The first assumption causes the first term on the right hand side of (2) to vanish. The second assumption implies the unpredictability of forecast errors of inflation at the moment that the expectation is formed (that is, errors in the inflation rates expected at $t$ to occur during the life of the bond, are uncorrelated; see Mishkin, 1991). The third assumption justifies neglecting risk premia in equation (2). Violation of any of these assumptions makes the interpretation of the yield curve more complex and reduces its value in forecasting changes in future inflation.

On the other extreme, if prices are fixed, then nominal yield spreads are a reflection of real spreads, which contain information regarding future real economic activity (Mishkin, 1990a, 1991). ${ }^{5}$ This theoretical relationship between the yield spread and real economic activity is not clear-cut, however. As can be seen from a standard IS-LM model for a small open economy (see, for example, Dornbusch, 1980, pp. 175-192), the nature of the relationship between the yield slope and future real activity depends on the nature of the shocks hitting the economy and the speed of price adjustment. ${ }^{6}$ In the presence of real economic shocks and sticky prices, a positive yield spread is indicative of a future economic upswing. On the other hand, when monetary shocks dominate, a positive yield spread indicates a weakening of future economic activity. In the former case, the expected outward shift of the IS-curve raises expected future short term rates (because the expected increase in income raises money demand), and this expectation is translated into higher current long-term rates. The information content is thus based on the expected effects of a real-economic disturbance on interest rates. In the latter case, a monetary shock such as the expectation of a future monetary tightening also raises future short-term rates and current long-term rates, but the resulting steepening of the yield curve now indicates a future decline in economic activity. The information content reflects the expected effects of monetary policy via interest rates on economic activity. When prices are flexible in the short run, the abovementioned analysis of shocks becomes more complicated because we have to take inflation expectations into account. In reaction to the monetary shock, future

\footnotetext{
$5 \quad$ Mishkin interprets the real yield spread (long minus short) as the difference between long-run and shortrun marginal productivity of capital. When the peak of the business cycle is reached, productive potential is fully used, short run capital productivity is high vis-à-vis capital productivity in the longer run, when activity is expected to weaken. When the trough is reached, current capital productivity is low, but the expectation of a future upswing implies higher long-run productivity. Thus the real yield spread and the future business cycle are positively related. An alternative theoretical explanation of a (positive) relationship between the real yield spread and future real activity is presented by Harvey (1988) with the use of the CAPM.

In this model, spending decisions are influenced by the long term rate, money market equilibrium by the short-term rate, and the long term rate by expected future short-term rates. Moreover, perfect capital mobility and fixed exchange rates are assumed to prevail. These assumptions are admittedly stringent, but in our view admissable given the illustrative character of the analysis based on the model.
} 
real short-term rates will increase, but, if monetary policy is considered to be credible, future nominal short-term rates can decline, especially for those expected to prevail in the more distant future. With a credible monetary policy, the nominal yield spread will decline and will be indicative of a future increase in economic activity: the relationship will again be positive. ${ }^{7}$

The preceeding analysis illustrates that, in general, the yield curve possesses information regarding both future inflation and future real economic activity. We now take up the issue of establishing empirically the information content of the yield curve.

\section{An empirical investigation of the usefulness of the yield curve for the eurosystem}

In this section, we focus on the effectiveness of the yield curve in forecasting future movements in inflation and real output. Our objective here is not to construct the best possible forecast for inflation or real output, but to check whether the yield curve passes what we consider to be a 'minimal' test for qualifying as information variable for monetary policy. We define this minimal test as a significant marginal information content of the yield curve in forecasting inflation and real output, i.e. the yield spread should contribute significantly to the forecasting power, over-and-above the information that past patterns on inflation and output provide.

We approach this issue in a multi-country setting, with explicit attention to the euro area. To this end, we collected data from the BIS and Datastream databases on the CPI, real GDP, long-term interest rates (yields on benchmark bonds) and short-term interest rates (three month interest rates) for 12 countries: Austria, Belgium, Germany, France, Ireland, Italy, the Netherlands, Denmark, UK, Switzerland, Japan and the US. ${ }^{8}$ In addition we calculated euro area-wide equivalents for these variables, using the methodology of Albers, Bijsterbosch and Vijselaar (forthcoming) ${ }^{9}$, and, for the interest rates, of the ECB (ECB,1999). Our data base consists of quarterly data, spanning the period 1970-1998.

The analysis of fiscal shocks also becomes more complicated when price adjustments have to be taken into account. See Blanchard and Fischer (1989, p. 536) for a discussion.

Alonso et al. (1997) conduct an empirical experiment similar to ours for Spain.

I essence, the GDP series for the euro area is constructed as a weighted average of individual countries' GDP, and the CPI series is similarly constructed, using private consumption as weights. The latter are fixed and pertain to 1995 . 
We start by investigating the time series properties of the data. Table 1 presents results from applying the Adjusted Dickey-Fuller unit root test on the variables involved. Table 1 shows that the inflation rate and the level of real gdp are non-stationary, as opposed to the yield spread, which is stationary. ${ }^{10}$ First-differencing the inflation rate and calculating the growth rate of real output gdp generate stationary series (output growth in Japan being the single exception). Note that the implication that the yield spread provides information only on the change in the inflation rate is consistent with equation (2) above.

\begin{tabular}{|c|c|c|c|c|c|c|c|c|c|c|}
\hline \multirow[b]{3}{*}{ Austria } & \multicolumn{4}{|c|}{ inflation rate } & \multicolumn{4}{|c|}{ gdp } & & \\
\hline & \multicolumn{2}{|c|}{ level } & \multicolumn{2}{|c|}{ difference } & \multicolumn{2}{|c|}{ level } & \multicolumn{2}{|c|}{ growth rate } & \multicolumn{2}{|c|}{ yield spread } \\
\hline & 2.78 & $(\mathrm{t}, 12)$ & $5.58^{* *}$ & $(n, 3)$ & 1.95 & $(t, 1)$ & $3.11^{*}$ & $(c, 8)$ & $2.62^{* *}$ & $(n, 3)$ \\
\hline Belgium & 2.79 & $(\mathrm{t}, 12)$ & $3.54^{\star *}$ & $(n, 11)$ & 1.61 & $(t, 6)$ & $3.35^{\star}$ & $(\mathrm{c}, 7)$ & $4.09^{\star \star}$ & $(\mathrm{n}, 1)$ \\
\hline Germany & 1.25 & $(\mathrm{t}, 12)$ & $3.56^{\star *}$ & $(n, 11)$ & 3.16 & $(\mathrm{t}, 11)$ & $3.28^{*}$ & $(c, 12)$ & $3.34^{\star *}$ & $(\mathrm{n}, 1)$ \\
\hline France & 2.64 & $(\mathrm{t}, 12)$ & $3.97^{* *}$ & $(n, 11)$ & 3.21 & $(t, 3)$ & $2.98^{*}$ & $(c, 8)$ & $3.34^{* *}$ & $(\mathrm{n}, 1)$ \\
\hline Ireland & 2.53 & $(\mathrm{t}, 12)$ & $3.78^{* *}$ & $(n, 11)$ & 1.47 & $(c, 12)$ & $3.22^{* *}$ & $(n, 1)$ & $3.85^{\star *}$ & $(\mathrm{n}, 1)$ \\
\hline Italy & 3.16 & $(\mathrm{t}, 12)$ & $3.16^{* *}$ & $(n, 8)$ & 1.66 & $(c, 3)$ & $4.16^{\star *}$ & $(t, 4)$ & $3.88^{* *}$ & $(\mathrm{n}, 1)$ \\
\hline Netherlands & 1.86 & $(\mathrm{t}, 12)$ & $3.55^{\star \star}$ & $(n, 7)$ & 1.95 & $(c, 12)$ & $3.27^{\star}$ & $(\mathrm{c}, 11)$ & $4.31^{* *}$ & $(c, 1)$ \\
\hline Euro area & 3.01 & $(t, 5)$ & $3.49^{* *}$ & $(n, 4)$ & 2.26 & $(t, 2)$ & $3.00^{\star}$ & $(c, 12)$ & $2.77^{\star *}$ & $(\mathrm{n}, 1)$ \\
\hline Denmark & 3.21 & $(\mathrm{t}, 12)$ & $7.18^{* *}$ & $(n, 3)$ & 2.69 & $(t, 6)$ & $2.06^{*}$ & $(n, 8)$ & $4.00^{* *}$ & $(\mathrm{n}, 0)$ \\
\hline UK & 2.5 & $(\mathrm{t}, 12)$ & $5.04^{\star *}$ & $(n, 11)$ & 2.56 & $(t, 6)$ & $3.92^{\star \star}$ & $(c, 8)$ & $2.52^{*}$ & $(n, 1)$ \\
\hline Switzerland & 2.49 & $(\mathrm{t}, 4)$ & $3.76^{* *}$ & $(n, 7)$ & 3.05 & $(\mathrm{t}, 12)$ & $3.09^{\star *}$ & $(\mathrm{n}, 12)$ & $2.19^{*}$ & $(n, 9)$ \\
\hline Japan & 2.78 & $(\mathrm{t}, 12)$ & $4.75^{\star *}$ & $(n, 7)$ & 0.51 & $(\mathrm{c}, 12)$ & 2.25 & $(\mathrm{t}, 12)$ & $4.63^{\star *}$ & $(\mathrm{t}, 6)$ \\
\hline US & 2.91 & $(\mathrm{t}, 12)$ & $4.53^{* *}$ & $(\mathrm{n}, 11)$ & 2.19 & $(c, 12)$ & $3.00^{*}$ & $(c, 12)$ & $3.57^{*}$ & $(\mathrm{t}, 12)$ \\
\hline
\end{tabular}

Notes: presented are absolute values of the ADF test. Figures within brackets represent the specification of the deterministic process and of the number of lagged terms, respectively.t=linear trend and intercept, $\mathrm{C}=$ intercept, $n=$ neither. ${ }^{* *}\left({ }^{*}\right)=$ significant at $1 \%(5 \%)$ level. Sample: 1970:1-1998:4. Inflation rate and gdp growth rate are defined in terms of changes versus previous corresponding period.

We next construct univariate autoregressive models for the stationary transformation of the inflation rate and real gdp, ie the change in the inflation rate and the growth rate of real output respectively:

$$
x(t)=\alpha+\sum_{i=1}^{p} x(t-i)+\varepsilon(t)
$$

where $x$ represents the variable of interest to the policy maker, ie the change in the inflation rate or the growth of real output. The maximum number of lags, $p$ in equation (3), is chosen using the well-known Schwartz Bayesian Criterion (SBC), an information

\footnotetext{
10 The inflation rate is measured as the change in the CPI vis-à-vis the previous corresponding period. The gdp growth rate is measured in a similar fashion, and the yield spread is defined as the differential between long-term and short-term interest rates. In calculating and using the inflation rate and the growth rate of output in this way, we are side-stepping the issue of seasonal unit roots (Hylleberg et al., 1990).
} 
criterion similar to the AIC but with a larger penalty for additional coefficients. ${ }^{11}$ We look for the lag length with minimal SBC, subject to the restriction that the residuals of the model should be serially uncorrelated. Whenever the minimal SBC violates this restriction, the lag length is determined based on the joint significance of the included lags, the joint insignificance of the excluded lags, and the Lagrange multiplier test for serial correlation. As a starting point, we impose a maximum number of 12 lags, implying that the maximal lag in the monetary transmission process is 3 years, which does not seem to be unduly restrictive given the available empirical evidence (Mishkin, 1995, 1996). Moreover, when testing for less than the maximum number of 12 lags, we impose some standardisation in order to keep the analysis (which is based on a relatively large number of countries) tractable. That is, we considered horizons of 4, 6, 8, and 12 quarters in our models.

Table 2 Selection of lag length in univariate AR models

\begin{tabular}{|c|c|c|c|c|c|c|c|c|c|c|}
\hline \multirow[b]{2}{*}{ quarters } & \multicolumn{5}{|c|}{ change in inflation rate } & \multicolumn{5}{|c|}{ gdp growth rate } \\
\hline & 4 & 6 & 8 & 12 & $\mathrm{LM}$ (sc) & 4 & 6 & 8 & 12 & $\mathrm{LM}(\mathrm{sc})$ \\
\hline Austria & $7.35^{\star}$ & 7.27 & 7.22 & 7.06 & 0.99 & $5.81^{*}$ & 5.74 & 5.69 & 5.69 & 1.85 \\
\hline Belgium & 7.07 & 7.08 & $7.3^{*}$ & 6.97 & 0.57 & 10.09 & 10.06 & $11.04^{*}$ & 10.94 & 0.53 \\
\hline Germany & 7.58 & 7.55 & 7.5 & $7.44^{*}$ & 0.26 & 7.01 & $7.04^{*}$ & 6.98 & 6.98 & 1.95 \\
\hline France & 7.39 & 7.38 & $7.42^{*}$ & 7.32 & 1.66 & 6.69 & $6.81^{*}$ & 6.72 & 6.69 & 1.41 \\
\hline Ireland & $5.24^{*}$ & 5.18 & 5.13 & 5.02 & 2.58 & 10.09 & 10.04 & 10.59 & $10.8^{*}$ & 0.47 \\
\hline Italy & 5.97 & 5.96 & 5.96 & $5.9^{\star}$ & $4.24^{\star \star}$ & 5.92 & $5.96^{*}$ & 5.9 & 5.75 & 0.5 \\
\hline Netherlands & $7.59^{\star}$ & 7.52 & 7.5 & 7.34 & 2.26 & 5.38 & $5.51^{*}$ & 5.45 & 5.31 & 0.99 \\
\hline Euro area & $8.32^{*}$ & 8.29 & 8.24 & 8.16 & 0.8 & 6.66 & $6.68^{*}$ & 6.6 & 6.5 & 0.69 \\
\hline Denmark & 5.94 & 5.85 & 5.91 & $5.89^{*}$ & $3.32^{\star *}$ & 4.7 & 4.68 & 4.67 & $4.67^{\star}$ & 0.93 \\
\hline UK & 5.58 & 5.55 & 5.56 & $5.6^{*}$ & $3.58^{\star *}$ & 5.86 & 5.87 & $5.92^{*}$ & 5.74 & 0.52 \\
\hline Switzerland & $7.01^{*}$ & 6.95 & 6.92 & 6.78 & 1.84 & 7.12 & 7.23 & 7.19 & $7.31^{*}$ & $5.4^{\star \star}$ \\
\hline Japan & 6.52 & 6.45 & $6.58^{*}$ & 6.49 & $3.5^{\star \star}$ & 6.22 & $6.23^{*}$ & 6.15 & 5.86 & 0.64 \\
\hline US & 7.25 & 7.19 & $7.32^{*}$ & 7.23 & 1.77 & $5.98^{*}$ & 5.95 & 5.86 & 5.85 & 2.24 \\
\hline
\end{tabular}

Notes: presented are absolute values of Schwartz Information Criterium, except for the columns headed by

$\mathrm{LM}(\mathrm{sc})$, which provide values for the Lagrange multiplier test for serial correlation in the residuals of the final model.

${ }^{*}=$ selected lag length, ${ }^{* *}=$ significant at $1 \%$. All models are estimated on the longest available identical sample period. Selection of lag length based on the information criterium, remaining autocorrelations and joint (in)significance of (ex) included lags.

Table 2 presents the results of our procedure for determining the number of lags in the univariate processes for the change in the inflation rate and the growth rate of output. It follows that, for the euro area, the lag length selected in the model of the change in the inflation rate is 4 quarters. However, when comparing outcomes for individual euro area countries, it becomes clear that there exists considerable variation in the 'optimal' lag length, with Italy and Germany, for example, showing a horizon of 12 quarters. A horizon of 4 quarters seems relatively short compared to the results for the UK, Japan, and the US. In the model for output

$11 \quad$ Although the SBC will always select a more parsimonious model than the AIC, we prefer the former over the latter because of its superior large-sample properties. 
growth, a horizon of 6 quarters figures most prominently within the euro area. Apart from some serial correlation, the final AR-models show relatively few signs of misspecification. ${ }^{12}$

Having estimated the univariate autoregressive processes for the change in the inflation rate and the growth rate of real output, we next consider whether these processes can be improved by introducing the yield spread. That is, we estimate:

$$
x(t)=\alpha+\sum_{i=1}^{p} x(t-i)+\sum_{j=1}^{q} y \text { spread }(t-j)+\varepsilon(t)
$$

Since all the variables considered are stationary, we need not take up the issue of cointegration here. ${ }^{13,14}$ In stead, we add 12 lags of the yield spread to the univariate models for the variables of interest to the policy maker, and test the joint significance of these new regressors.

\begin{tabular}{|c|c|c|}
\hline & change in inflation rate & gdp growth rate \\
\hline Austria & 0.82 & 1.01 \\
\hline Belgium & $2.53^{*}$ & 0.45 \\
\hline Germany & 0.67 & 1.05 \\
\hline France & 1.82 & $2.42^{*}$ \\
\hline Ireland & 0.23 & 0.89 \\
\hline Italy & $2.35^{*}$ & 0.65 \\
\hline Netherlands & 1.48 & 1.72 \\
\hline Euro area & 0.4 & 1.38 \\
\hline Denmark & 1.64 & 0.43 \\
\hline UK & 1.23 & 1.3 \\
\hline Switzerland & $2.14^{*}$ & $2.04^{*}$ \\
\hline Japan & 0.43 & 1.28 \\
\hline US & $2.25^{\star}$ & $2.74^{*}$ \\
\hline
\end{tabular}

Notes: presented are values of a F-test on the joint significance of 12 lagged yield spreads in the AR models presented in table 2.

Sample 1970:1-1998:4. ${ }^{*}=$ significant at 5\%

\footnotetext{
12 Based on Ramsey's RESET test for misspecification, which shows a pattern similar to the serial correlation test reported in the table. The RESET test is not reported here in order to save space, but available on request from the authors.

Moreover, cointegration tests indicate that, for nearly all countries studied, the level of real GDP and the inflation rate are not cointegrated. This further validates our specification in terms of changes.
} 
Table 3 presents the results of the F-test on exclusion of the 12 lags of the yield spread. The results strongly suggest that the yield curve has only a limited value as an indicator: out of 13 countries, only in 4 (inflation rate) or even 3 (gdp) cases are the lagged yield spreads jointly significant. Only in two countries (Switzerland and the US) is the yield spread significant in predicting changes in the inflation rate as well as real output growth. Moreover, these cases are concentrated outside the euro area. No evidence is found for the euro area that the yield spread is significant in the AR-models for either the inflation rate or real output. Within the euro area, only in Belgium and Italy (inflation) and France (output) the evidence indicates significant yield spreads.

As a follow-up, we investigate in more detail the models for which the yield spread proved to be significant. For these models, we select the number of lags for the yield spread in a similar way to table 2 (note that this selection is made conditional on the number of lags for the change in the inflation rate and growth rate of output as determined earlier). The results are presented below.

Table 4 Selection of lag length of vield spread in bivariate AR models

\begin{tabular}{|c|c|c|c|c|c|c|c|c|c|c|}
\hline \multirow[b]{2}{*}{ quarters } & \multicolumn{5}{|c|}{ change in inflation rate } & \multicolumn{5}{|c|}{ gdp growth rate } \\
\hline & 4 & 6 & 8 & 12 & $\mathrm{LM}(\mathrm{sc})$ & 4 & 6 & 8 & 12 & $\mathrm{LM}(\mathrm{sc})$ \\
\hline \multicolumn{11}{|l|}{ Austria } \\
\hline Belgium & 6.99 & $7.02^{*}$ & 6.95 & 6.8 & 0.59 & & & & & \\
\hline \multicolumn{11}{|l|}{ Germany } \\
\hline $\begin{array}{l}\text { France } \\
\text { Ireland }\end{array}$ & & & & & & $6.77^{*}$ & 6.74 & 6.67 & 6.53 & 1.22 \\
\hline Italy & 5.83 & 5.75 & 5.68 & $5.67^{\star}$ & 1.59 & & & & & \\
\hline \multicolumn{11}{|l|}{ Netherlands } \\
\hline \multicolumn{11}{|l|}{ Euro area } \\
\hline \multicolumn{11}{|l|}{ Denmark } \\
\hline UK & & & & & & & & & & \\
\hline $\begin{array}{l}\text { Switzerland } \\
\text { Japan }\end{array}$ & $6.84^{*}$ & 6.8 & 6.76 & 6.61 & 0.63 & $7.29^{*}$ & 7.27 & 7.2 & 7.04 & 1.72 \\
\hline US & 7.23 & $7.13^{*}$ & 7.06 & 7.06 & 1.32 & $5.98^{*}$ & 5.93 & 5.86 & 5.75 & 2.53 \\
\hline
\end{tabular}

Notes: presented are absolute values of Schwartz Information Criterium, except for the columns headed by

LM(sc), which provide values for the Lagrange multiplier test for serial correlation in the residuals of the final model.

${ }^{*}=$ selected lag length, ${ }^{* *}=$ significant at $1 \%$. All models are estimated on the longest available identical sample period. Selection of lag length based on the information criterium, remaining autocorrelations and joint (in)significance of (ex) included lags.

It follows from table 4 that the optimal lag length for the yield spread, conditional on the past history of changes in the inflation rate and the growth of real output, is 4 or 6 quarters for the change in the inflation rate and 4 quarters for the output growth model, the latter

14 A word of caution is in order here. It is well known that the power of unit root tests is low, especially in samples covering a relatively short time span (Campbell and Perron, 1991). If, contrary to the findings in table 1 , the inflation rate and the growth rate of GDP were both non-stationary and jointly cointegrated, we need not differentiate between them when analysing their relationship with the yield curve, given the existence of a long-run equilibrium relationship between inflation and real output. 
corroborating the findings of Berk and Bikker (1995). Again, the final AR-models showed relatively few signs of misspecification. ${ }^{15}$ Given the fact that the time period in our sample includes a great deal of structural changes and policy shifts, we took a special interest in the stability of our final models. Both statistical tests performed (Chow breakpoint test calculated at 5-year intervals during the sample period and the CUSUM test; see Appendix) by and large failed to find significant signs of parameter instability since the mid 1980's, with the equation for US GDP being the exception. ${ }^{16}$

Having constructed bivariate models for the change in the inflation rate and the growth in real output, the policy maker takes a natural interest in the performance of these models in forecasting changes in inflation and real output growth, respectively. To this end, we compare autoregressive models with and without the yield spread, and approach the forecasting performance within-sample as well as out-of-sample. The former consists of comparing RMSE of both models estimated using all available data.

The latter is based on an estimation of the model using data up to and including 1989, and using this model to make forecasts for the period 1990-1998. We generate static forecasts, thereby using the information the policy maker would have had at the moment the prediction was made. 
Table 5a Comparing forecasting performance of AR models: within sample forecasts

\begin{tabular}{lcccccc}
\hline & \multicolumn{3}{c}{ change in inflation rate } & & \multicolumn{2}{c}{ gdp growth rate } \\
& with & without & difference & with & without & difference \\
\hline $\begin{array}{l}\text { Austria } \\
\text { Belgium }\end{array}$ & 0.52 & 0.59 & -0.07 & & & \\
$\begin{array}{l}\text { Germany } \\
\text { France }\end{array}$ & & & & & & \\
$\begin{array}{l}\text { Ireland } \\
\text { Italy }\end{array}$ & 0.88 & 0.93 & -0.05 & & & \\
$\begin{array}{l}\text { Netherlands } \\
\text { Euro area }\end{array}$ & & & & & & \\
$\begin{array}{l}\text { Denmark } \\
\text { UK }\end{array}$ & & & & & & \\
$\begin{array}{l}\text { Switzerland } \\
\text { Japan }\end{array}$ & 0.65 & 0.65 & 0 & & & \\
US & 0.47 & 0.5 & -0.03 & 1 & & \\
\hline
\end{tabular}

Notes: presented are values (in \%) of the RMSE of models with or without the yield spread. Difference is measured in percentage points. Sample: 1970:1-1998:4

Table $5 \mathrm{~b}$ Comparing forecasting performance of AR models:out-of-sample forecasts

\begin{tabular}{|c|c|c|c|c|c|c|}
\hline & \multicolumn{3}{|c|}{ change in inflation rate } & \multirow[b]{2}{*}{ with } & \multicolumn{2}{|c|}{ gdp growth rate } \\
\hline & with & without & difference & & without & difference \\
\hline Austria & & & & & & \\
\hline $\begin{array}{l}\text { Belgium } \\
\text { Germany }\end{array}$ & 0.94 & 1.05 & -0.11 & & & \\
\hline $\begin{array}{l}\text { France } \\
\text { Ireland }\end{array}$ & & & & 0.91 & 0.74 & 0.17 \\
\hline Italy & 1.24 & 0.57 & 0.67 & & & \\
\hline $\begin{array}{l}\text { Netherlands } \\
\text { Euro area }\end{array}$ & & & & & & \\
\hline Denmark & & & & & & \\
\hline UK & & & & & & \\
\hline $\begin{array}{l}\text { Switzerland } \\
\text { Japan }\end{array}$ & 0.68 & 0.71 & -0.03 & 0.53 & 0.39 & 0.14 \\
\hline US & 0.72 & 0.79 & -0.07 & 1.18 & 1.02 & 0.16 \\
\hline
\end{tabular}

Notes: presented are values (in \%) of the RMSE of models with or without the yield spread. The estimation period is 1970:1-1989:4, and the model is used to generate a static forecast for 1990:1-1998:4

The results are presented in table 5, and are disappointing. The gain in forecasting power of adding the yield curve is fairly limited, both within-sample and out-of-sample. It is even completely absent as regards out-of-sample forecasts for real GDP. The latter implies that the policy maker, when making forecasts for the 1990's based on models estimated up to the end of the 1980's, would have been worse off when including the yield spread in simple autoregressive models for the change in real output growth. 
In addition to the static out-of-sample forecasts presented in table $5 \mathrm{~b}$, we also constructed a dynamic simulation on two different horizons. We estimated the models, both with and without the yield spread, over the period ending in 1989, and performed a dynamic out-of sample forecast for the period 1990-1994 (table 6a).

Table 6a Comparing forecasting performance of AR models: dynamic forecasts estimation period ending in 1989-IV. Dynamic estimation: 1990-1994

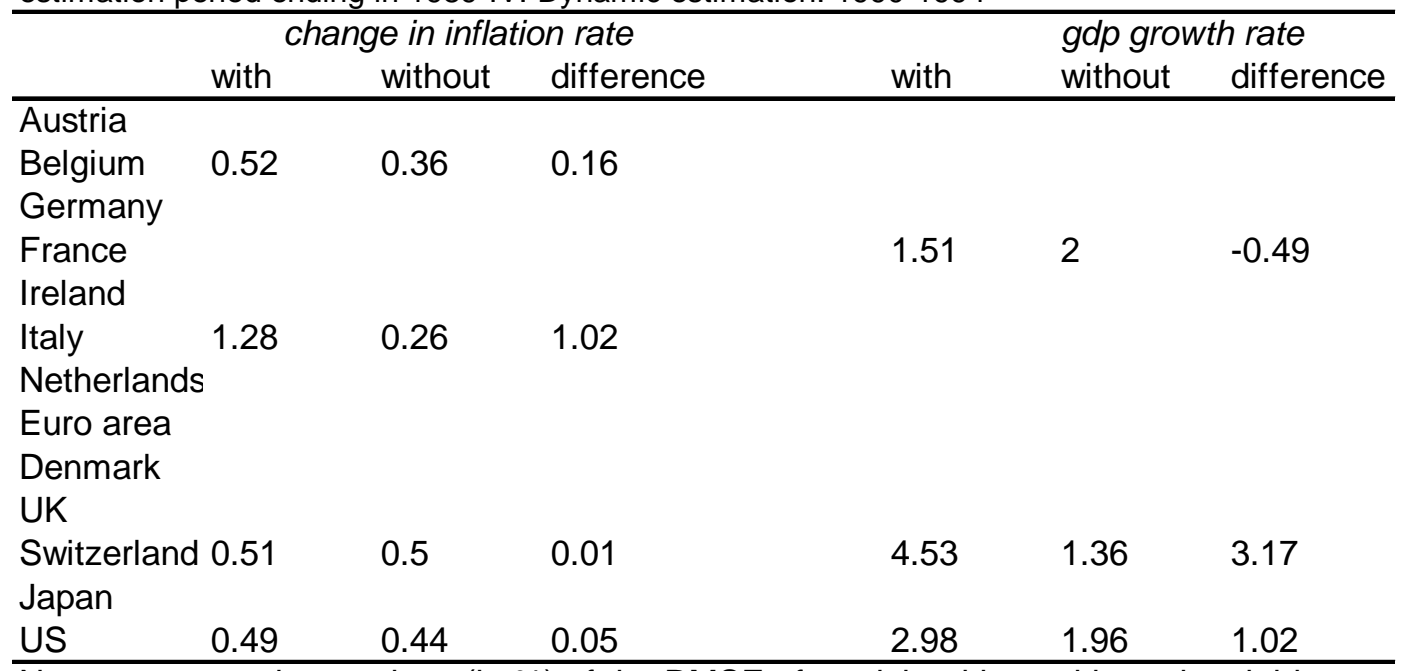

Notes: presented are values (in \%) of the RMSE of models with or without the yield spread. Difference is measured in percentage points

Table 6b Comparing forecasting performance of AR models: dynamic forecasts estimation period ending in 1994-IV. Dynamic estimation: 1995-1998

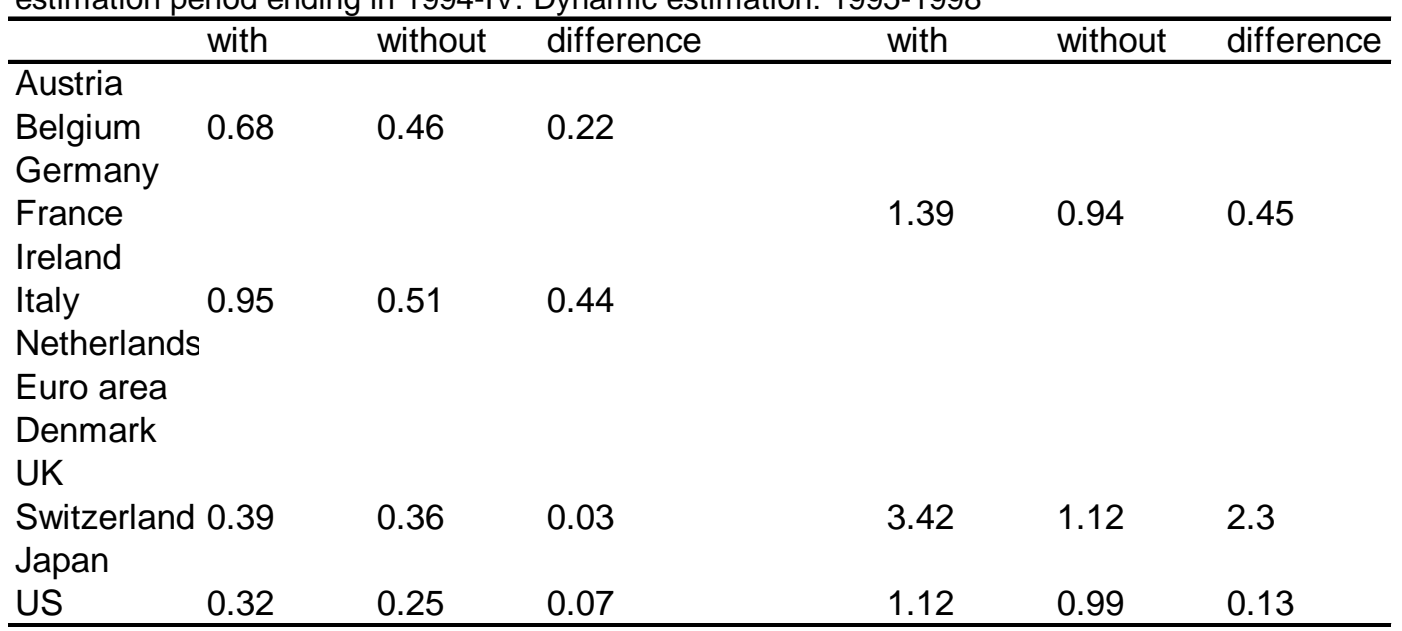

Notes: presented are values (in \%) of the RMSE of models with or without the yield spread. Difference is measured in percentage points

We repeated this exercise for the models estimated up to and including 1994, dynamically forecasting the period 1995-1998 (table 6b). This exercise allows us to further investigate the predictive performance of the AR-models. The results are even more detrimental as regards the gain in forecasting power of adding the yield curve: only in the equation for 
French GDP, dynamically simulated over the first half of his decade, did including the yield spread result in an improvement in forecasting performance as measured by the RMSE. In all other cases, the policy maker would have been worse off when including the yield spread in the simple forecasting models considered above.

All in all, these simple empirical exercises indicate that the value of the yield spread as an information variable with respect to future movements in inflation or real output is rather limited. This is in line with earlier findings, such as for example Koedijk and Kool (1995), Sauer and Scheide (1995), and Tzavalis and Wickens (1996). ${ }^{17}$ For most countries, especially those within the euro area (and also for the euro area as a whole), the yield spread does not appear to contain information that is not already contained in the history of inflation and output. Moreover, for those cases in which some marginal information content (as defined earlier) could be established, the improvement in forecasting performance was small or even imaginary.

These results are of course subject to several caveats. To start with, our measure of the yield spread involves long-term interest rates (up to 10 years) minus short-term interest rates (3 month bonds). Our results are therefore specific for this segment of the yield curve; it could well be the case that analyses using different segments yield different results. ${ }^{18}$ Moreover, our measure of the yield spread overshoots even the longest lags considered in the univariate autoregressive processes (ie 12 quarters). Our results therefore do not preclude the possibility that the yield spread reflects developments expected in the more distant future. ${ }^{19}$ However, this possibility can be regarded as rather remote, as there is some evidence suggesting that expectations after 2-3 years are flat (Berk and Knot, 1997). An important further caveat pertains to the rather simplistic view of measuring the information content. It ignores, for instance, more complex interactions between the information variable and policy goal, in which the yield curve could be used in combination with other variables to predict future movements in inflation and real output. Moreover, the methodology used (single equation estimation) implies a restriction on the dynamics of the modelled relationship between information and goal variables. A topic for future research would be to allow for a richer multivariate setting, for example within the VAR-framework (see Leeper, Sims and Zha, 1996, for an interesting application to monetary policy). Other objections relate to the projection of the results, obtained from

\footnotetext{
17 However, the body of empirical work on the subject is large, and the implications of this work are not clear cut. See Berk (1998) for a recent overview.

18 This could reconcile our findings with the work of others who find that the yield curve possesses significant information content, such as, for example, Jorion and Mishkin (1991), Bernard and Gerlach (1996), Estrella and Mishkin (1997), Gerlach and Smets (1997), and Schich (1999).

Estrella and Mishkin (1997) circumvent this horizon mismatch between the yield spread and the dynamic specification of the model by using forward rates which can be calculated on an annual basis.
} 
estimates based on pre-EMU data, to Stage Three of EMU. The start of the latter is a regime shift which is likely to give rise to Lucas (1976)-type of problems. Similarly, the structural changes induced by EMU will probably also make themselves present in European financial markets. The ensuing financial innovations could well mean that the (time series) behaviour of the 'true' euro area yield curve will be different from the historical yield curve constructed as a weighted average of national interest rates.

\section{Concluding remarks}

The empirical analysis suggests that the practical usefulness of the yield spread for predicting future movements in inflation and output in the euro area is limited. Moreover, it follows from the theoretical discussion that, even if a correlation could be established between these variables, this correlation may be a reflection of different economic phenomena, each warranting different policy reactions. First, a steepening can indicate an upward revision of inflationary expectations, in which case a monetary tightening is called for. Second, the steepening may reflect the expectation of an increase in capital productivity, higher real interest rates and an increase in activity. In this case, a tightening may or may not be warranted, depending on the current state of the business cycle. Third, a positive correlation may reflect the expectation of a future monetary tightening by a credible monetary policymaker. The possibility of multiple valid theoretical explanations of a single observed relationship corroborates the findings of Turnovsky (1989) and McCallum (1994), who conclude that the response of the term structure is highly sensitive to the nature of the underlying shocks impinging on the economy.

There are also other reasons why the Eurosystem should be cautious in using the yield curve for monetary policy purposes. As Mishkin (1991) notes, the information content is sensitive to the relative variability of expected future inflation changes and changes in real interest rates, as well as to the correlation between changes in these two variables. Any change in the conduct of monetary policy, such as using the yield curve as an information variable, i.e. a guide for monetary policy, is likely to change the correlation and relative variability of changes in expected future inflation and in real interest rates. The forecasting quality of the yield curve for the path of future inflation could therefore change dramatically, making the yield slope a poor guide for monetary policy. This is, of course, an example of the Lucas (1976) critique. Similar arguments can be used to explain the observed differences in the information content across countries and in time. According to

Gerlach and Smets (1997), the information content is largest in countries where short-term 
interest rates are easiest to predict. Predictability can be a manifestation of a credible monetary policy. Regime shifts can destroy this credibility (especially if they occur frequently), causing the behaviour of economic agents to change, which has consequences for the empirical validity of the information content. In a similar fashion, central banks in different countries can pursue identical policies, but, because of differences in credibility, this policy can induce different behaviour of economic agents in their countries. The implication is that the information content of the yield curve differs across countries and over time. Taken together, the outcome of the theoretical discussion and the results of our empirical experiment suggest, in our view, that considerable care should be taken in using the yield curve as information variable for the monetary policy of the Eurosystem. 


\section{References}

Alonso, F., Ayuso, J. and Martinez Pages, J. (1997), 'How informative are financial asset prices in Spain?', Working Paper, no 9726, Banca de España.

Albers, R.M. Bijsterbosch, M. and Vijselaar, F. (forthcoming), 'The real economy of the euro area', in: Bergeijk, P.A.G. van, Berndsen, R.J. and Jansen, J. (eds), Euro Area Economics, Edward Elgar, Cheltenham.

Angeloni, I. and Rovelli, R. (1999), 'Monetary Policy and Interest Rates', Macmillan, London.

Berk, J.M. (1998), 'The Information Content of the Yield Curve for Monetary Policy: A Survey', De Economist, 146, pp. 303-320.

Berk, J.M. and Bikker, J.A. (1995), 'International interdependence of business cycles in the manufacturing industry: the use of leading indicators for forecasting and analysis', Journal of Forecasting, 14, pp. 1-23.

Berk, J.M., Kakes, J.I. and Houben, A.C.J.F. (forthcoming), 'Monetary Policy and Strategy of the Eurosystem', in: Bergeijk, P.A.G. van, Berndsen, R.J. and Jansen, J. (eds), Euro Area Economics, Edward Elgar, Cheltenham.

Berk, J.M. and Knot, K. (1997), 'Co-movements in long-term interest rates and the role of exchange rate expectations: Evidence from survey data', MEB Series no 1997-08, De Nederlandsche Bank.

Bernard, H. and Gerlach, S. (1996), 'Does the term structure predict recessions? The international evidence', BIS Working Paper, no 37, BIS, Basle.

Blanchard, O.J. and Fischer, S. (1989), 'Lectures on macroeconomics', The MIT Press, Cambridge (MA).

Campbell, J.Y. and Perron, P. (1991), 'Pitfalls and opportunities: what macroeconomists should know about unit roots', in Blanchard, O.J. and Fisher, S. (eds), NBER Macroeconomics Annual 1991, pp. 141-219.

Deacon, M. and Derry, A. (1994), 'Estimating the Term Structure of Interest Rates', Working Paper no 24, Bank of England, London.

Estrella, A. and Mishkin, F.S. (1997), 'The predictive power of the term structure of interest rates in Europe and the United States: implications for the European Central Bank', European Economic Review, 41, pp. 1375-1401.

European Central Bank (1999), Monthly Bulletin, July 1999, European Central Bank, Frankfurt am Main, pp. 21*.

Dornbusch, R. (1980), 'Open economy macroeconomics', Basic Books, New York.

Fuhrer, J.C. (1997), 'Central Bank Independence and Inflation Targeting: Monetary Policy Paradigms for the Next Millennium?', New England Economic Review, jan/feb 1997, pp. 19-36.

Gerlach, S. and Smets, F. (1997), 'The Term Structure of Euro-Rates: Some Evidence in Support of the Expectations Hypothesis', Journal of International Money and Finance, 16, pp. 305-321.

Hardouvelis, G.A. (1994), 'The Term Structure Spread and Future Changes in Long and Short Rates in the G7 Countries', Journal of Monetary Economics, 33, pp. 255-283.

Harvey, C.R. (1988), 'The Real Term Structure and Consumption Growth', Journal of Financial Economics, 22, pp. 305-333.

Haubrich, J.G. and Dombrosky, A.M. (1996), 'Predicting Real Growth Using the Yield Curve', Economic Review 1996-I, Federal Reserve Bank of Cleveland, 32, pp. 26-35.

Hylleberg, S., Engle, R.F., Granger, C.W.J., Yoo, B.S. (1990), 'Seasonal integration and cointegration', Journal of Econometrics, 44, pp. 215-238.

Jondeau, E. and Ricart, R. (1999), 'The expectations hypothesis of the term structure: tests 
on US, German, French, and UK Euro-rates', Journal of International Money and Finance, 18, pp. 725-750.

Jorion, P. and Mishkin, F.S. (1991), 'A Multicountry Comparison of Term Structure Forecasts at Long Horizons', Journal of Financial Economics, 29, pp. 59-80.

Koedijk, K.G. and Kool, C.J.M. (1995), 'Future inflation and the information in international term structures', Empirical Economics, 20, pp. 217-242.

Leeper, E.M., Sims, C.A., and Zha, T. (996), 'What does monetary policy do?', Brookings Paper on Economic Activity, 2, pp. 1-78.

Lucas, R.E. (1976), 'Econometric Policy Evaluation: A Critique' in 'Studies in BusinessCycle Theory', R.E. Lucas,(ed), the MIT Press, Cambridge (MA), pp. 104-130, 1981.

McCallum, B.T. (1994), 'Monetary policy and the term structure of interest rates', Working Paper no 4938, NBER, Cambridge (MA).

Mishkin, F.S. (1990a), 'The Information in the Longer Maturity Term Structure about Future Inflation', Quarterly Journal of Economics, 105, pp. 815-828.

Mishkin, F.S. (1990b), 'What Does the Term Structure Tell Us About Future Inflation?', Journal of Monetary Economics, 25, pp. 77-95.

Mishkin, F.S. (1991), 'A Multi-Country Study of the Information in the Shorter Maturity Term Structure about Future Inflation', Journal of International Money and Finance, 10, pp. $2-22$.

Mishkin, F.S. (1995), 'Symposium on the monetary transmission mechanism', Journal of Economic Perspectives, 9, pp. 3-10.

Mishkin, F.S. (1996), 'The channels of transmission: lessons for monetary policy', NBER Working Paper no 5464, NBER, Cambridge (MA).

Modigliani, F. and Sutch, R. (1966), 'Innovations in Interest Rate Policy', American Economic Review, 56, pp.178-197.

Sauer, C. and Scheide, J. (1995), 'Money, Interest Rate Spreads and Economic Activity', Weltwirtschaftliches Archiv, 131, pp. 708-722.

Shigehara, K. (1996), 'The Options Regarding the Concept of a Monetary Policy Strategy', in 'Monetary Policy Strategies in Europe', Deutsche Bundesbank (ed), Vahlen-Verlag, München, pp. 7-44.

Schich, S.T. (1999), 'The information content of the German term structure regarding inflation', Applied Financial Economics, 9, pp. 385-395.

Shiller, R.J. (1990), The Term Structure of Interest Rates', in 'Handbook of Monetary Economics', B.M. Friedman and F.H. Hahn, (eds), North-Holland, Amsterdam, pp. 627-715. Svensson, L.E.O. (1994), 'Estimating and Interpreting Forward Interest Rates: Sweden 1992-1994', Working Paper no 4871, NBER, Cambridge (MA).

Turnovsky, S.J. (1989), The Term Structure of Interest Rates and the Effects of Macroeconomic Policy', Journal of Money, Credit and Banking, 21, pp. 321-347.

Tzavalis, E. and Wickens, M.R. (1996), Forecasting Inflation from the Term Structure', Journal of Empirical Finance, 3, pp. 103-122. 


\section{APPENDIX: Testing for parameter stability in the final AR models}

Tables A1 and A2 below present values of the Chow breakpoint test, with the breakpoint chosen (arbitrarily) to correspond with the beginning of 5-year intervals of the sample. The Appendix figures below plot values of the CUSUM test together with their 5\% critical values. Both the tables and the graphs indicate that the parameter estimates of our preferred AR models are reasonably stable, especially in the latter part of the sample.

Table A1 Chow breakpoint test: final equation for change in inflation

\begin{tabular}{|c|c|c|c|c|c|}
\hline break date & 1975-I & 1980-I & I I & 1990-I & 1995-1 \\
\hline Belgium & $\overline{N A}$ & $\begin{array}{l}2.33 \\
(0.01)\end{array}$ & $\begin{array}{l}1.32 \\
(0.21)\end{array}$ & $\begin{array}{l}1.27 \\
(0.24)\end{array}$ & $\begin{array}{l}1.00 \\
(0.46)\end{array}$ \\
\hline Italy & NA & $\begin{array}{l}3.78 \\
(0.00)\end{array}$ & $\begin{array}{l}1.45 \\
(0.13)\end{array}$ & $\begin{array}{l}0.58 \\
(0.93)\end{array}$ & $\begin{array}{l}0.5 \\
(0.97)\end{array}$ \\
\hline Switzerland & $\begin{array}{l}3.39 \\
(0.00)\end{array}$ & $\begin{array}{l}1.55 \\
(0.14)\end{array}$ & $\begin{array}{l}0.22 \\
(0.99)\end{array}$ & $\begin{array}{l}0.18 \\
(0.99)\end{array}$ & $\begin{array}{l}0.36 \\
(0.95)\end{array}$ \\
\hline US & NA & $\begin{array}{l}1.38 \\
(0.18)\end{array}$ & $\begin{array}{l}1.32 \\
(0.21)\end{array}$ & $\begin{array}{l}0.54 \\
(0.91)\end{array}$ & $\begin{array}{l}0.20 \\
(0.99)\end{array}$ \\
\hline
\end{tabular}

Notes: $p$-values in parentheses. NA=calculation not possible due to insufficient number of data

Table A2 Chow breakpoint test: final equation for change in GDP

\begin{tabular}{|c|c|c|c|c|c|}
\hline break date & 1975-I & 1980-I & $1985-1$ & 1990-I & 1995-1 \\
\hline Switzerlan & NA & 3.51 & 1.10 & 0.63 & $\begin{array}{l}0.29 \\
099\end{array}$ \\
\hline France & $\begin{array}{l}1.8 \\
(0.07)\end{array}$ & $\begin{array}{l}(0.00) \\
1.5 \\
(0.15)\end{array}$ & $\begin{array}{l}(0.37) \\
0.77 \\
(0.67)\end{array}$ & $\begin{array}{l}(0.86) \\
0.78 \\
(0.66)\end{array}$ & $\begin{array}{l}(0.99) \\
0.64 \\
(0.79)\end{array}$ \\
\hline US & $\begin{array}{l}1.04 \\
(0.41)\end{array}$ & $\begin{array}{l}1.6 \\
(0.12)\end{array}$ & $\begin{array}{l}3.00 \\
(0.00)\end{array}$ & $\begin{array}{l}2.35 \\
(0.02)\end{array}$ & $\begin{array}{l}0.58 \\
(0.81)\end{array}$ \\
\hline
\end{tabular}

Notes: $p$-values in parentheses. NA=calculation not possible due to insufficient number of data 
CUSUM test for change in inflation rates

Belgium

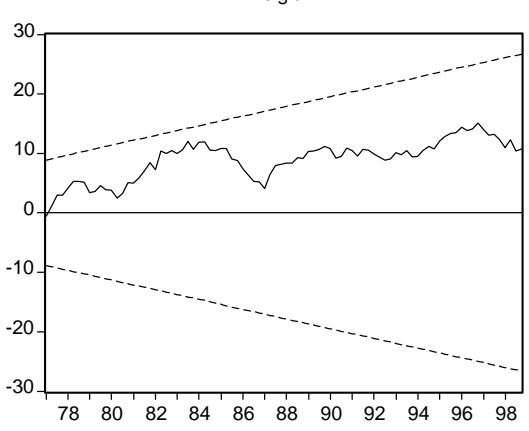

Switzerland

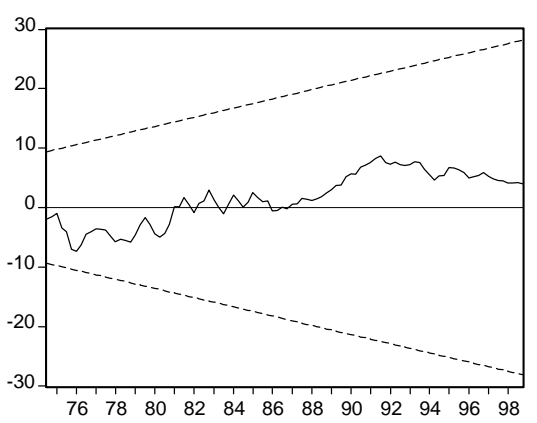

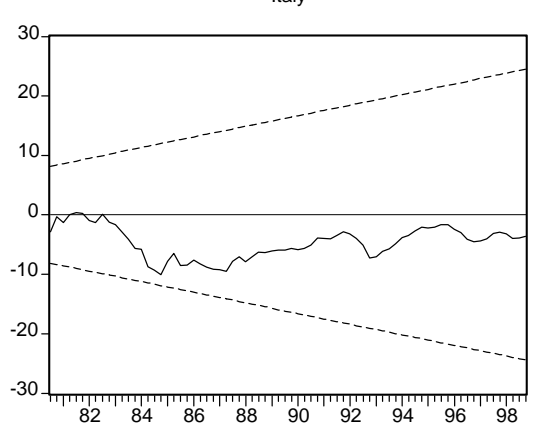

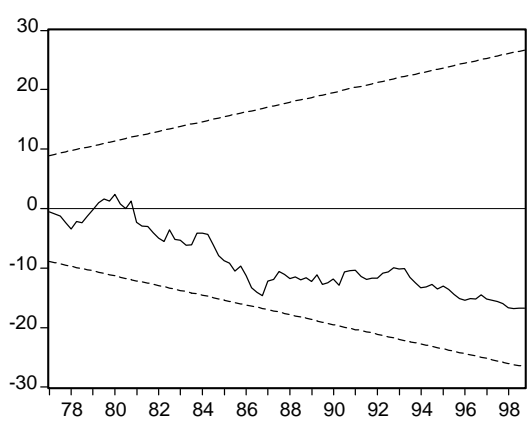

CUSUM --- 5\% Significance 
CUSUM test for change in real GDP

France

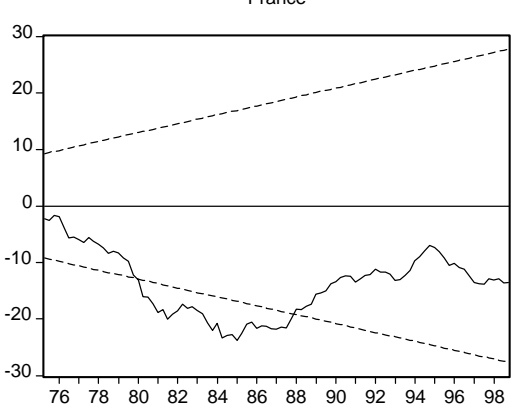

Switzerland

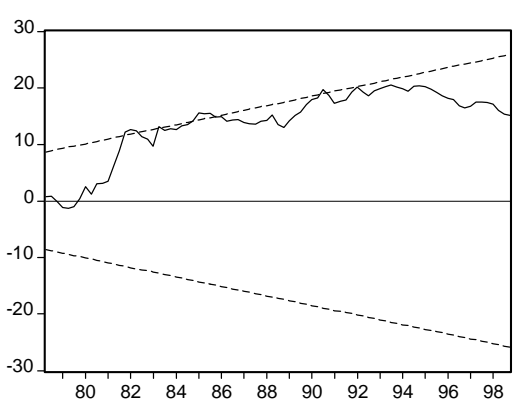

US

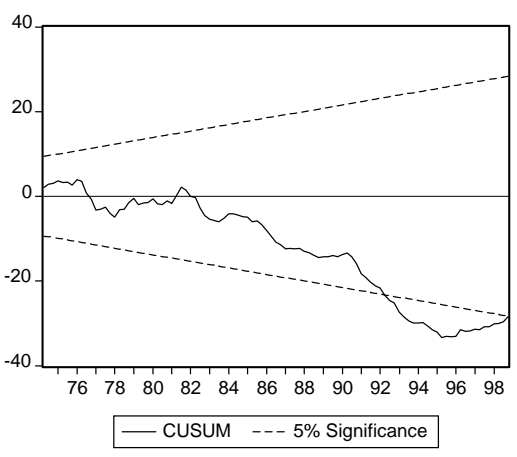




\section{European Central Bank Working Paper Series}

1 "A global hazard index for the world foreign exchange markets" by V. Brousseau and F. Scacciavillani, May 1999.

2 "W hat does the single monetary policy do? A SVAR benchmark for the European Central Bank" by C. Monticelli and O. Tristani, May 1999.

3 "Fiscal policy effectiveness and neutrality results in a non-Ricardian world" by C. Detken, May 1999.

4 "From the ERM to the euro: new evidence on economic and policy convergence among EU countries" by I. Angeloni and L. Dedola, May 1999.

5 "Core inflation: a review of some conceptual issues" by M. W ynne, May 1999.

6 "The demand for M3 in the euro area" by G. Coenen and J.-L. Vega, September 1999.

7 "A cross-country comparison of market structures in European banking" by 0 . de Bandt and E. P. D avis, September 1999.

8 "Inflation zone targeting" by A. O rphanides and V. W ieland, O ctober 1999.

9 "Asymptotic confidence bands for the estimated autocovariance and autocorrelation functions of vector autoregressive models" by G. Coenen, January 2000.

10 " $\mathrm{n}$ the effectiveness of sterilized foreign exchange intervention" by $\mathrm{R}$. Fatum, February 2000.

11 "Is the Yield Curve a useful Information Variable for the Eurosystem?" by J. M. Berk and P. van Bergeijk, February 2000.

12 "Indicator Variables for 0 ptimal Policy" by L. E. O. Svensson and M. W oodford, February 2000.

13 "Monetary policy with uncertain parameters" by U. Söderström, February 2000.

14 "Assessing N ominal Inco me Rules for Monetary Policy with Model and D ata Uncertainty" by G. D. Rudebusch, February 2000. 